\title{
THE EFFECT OF SOCIAL MEDIA TOWARD ORGANIC FOOD LITERACY AND PURCHASE INTENTION WITH AISAS MODEL
}

\author{
Salwa Inaayatullah Fannani*)1, Mukhamad Najib"), and Ma'mun Sarma*) \\ ${ }^{*}$ Department of Management, Faculty of Economics and Management, IPB University \\ Jl. Agatis, Campus of IPB Darmaga Bogor 16680, Indonesia
}

\begin{abstract}
This research aimed to analyze the effect of social media toward organic food literacy, analyze the effect of organic food literacy on consumer purchase intention, and analyze the components of the AISAS model that most effectively influence purchase intention. This research involved 150 respondents. Respondents consisted of social media followers from organic food sales account selected by the purposive sampling quota technique. Data collection was carried out using an online questionnaire. The SEM-PLS analysis in this research was used to analyze the direct effect of social media on organic food literacy and purchase intention based on AISAS modeling. The results of this study indicate that social media has a significant and positive effect on the attention, interest and search factors of consumers. Attention has a significant and positive effect on organic literacy from consumers. The share factor is the factor that most influences the consumer's buying interest of organic product. The influence given from influencer, friend, and relative testimonials is considered the most effective in attracting other consumers to buy. This can be used as a reference for organic product business people to find the most effective marketing method to attract consumer buying interest.
\end{abstract}

Keywords: social media, organic food literacy, purchase intention, aisas model, SEM-PLS

\begin{abstract}
Abstrak: Penelitian ini bertujuan untuk menganalisis pengaruh media sosial terhadap literasi pangan organik, menganalisis pengaruh literasi pangan organik terhadap minat beli konsumen, dan menganalisis komponen AISAS model yang paling efektif mempengaruhi minat pembelian. Penelitian ini melibatkan 150 responden. Responden terdiri dari followers media sosial akun penjualan pangan organik yang dipilih dengan teknik quota purposive sampling. Pengumpulan data dilakukan dengan menggunakan kuesioner online. Analisis SEM-PLS dalam penelitian ini digunakan untuk menganalisis pengaruh langsung media sosial terhadap literasi pangan organik dan niat beli berdasarkan pemodelan AISAS. Hasil dari penelitian ini menunjukan bahwa media sosial berpengaruh secara signifikan dan positif terhadap faktor attention, interest dan search dari konsumen. Attention berpengaruh secara signifikan dan positif terhadap literasi pangan organik dari konsumen. Faktor share merupakan faktor yang paling mempengaruhi minat beli dari konsumen terhadap sayuran organik. Pengaruh yang diberikan dari testimoni influencer, teman, kerabat dianggap paling effektif dalam menarik minat beli konsumen lainnya. Hal ini dapat dijadikan acuan bagi para pelaku bisnis produk organik untuk mencari cara pemasaran yang paling efektif untuk menarik minat beli konsumen.
\end{abstract}

Kata kunci: media social, literasi pangan organik, minat beli, model aisas, SEM$P L S$

${ }^{1}$ Corresponding author:

Email: salwa_inaayatullahf@apps.ipb.ac.id 


\section{INTRODUCTION}

Social media is the development of internet network through electronic communication. Social media becomes a means for consumers to share information, text, images, videos, and audio between one another and with companies and vice versa (Kotler \& Keller, 2012). Social media is currently a phenomenon that shows marketing developments as an alternative to strengthening the brands and products offered (Kaplan \& Haenlein, 2010). This raises the opportunity of marketing strategies that were originally conventionally switched to digital platforms.

In this development era, internet technology leads an advertising company named Dentsu to introduce a new buying process, namely AISAS (Attention, Interest, Search, Action, Share). This model (AISAS) help consumers to find information about a product before making a purchase decision. The search for product information is important because in the modern era, product development has become too fast and makes it difficult for consumers to distinguish one product from another. It also encourage consumer to become active in information searching before buying product instead of only receiving product information from others.

Sugiyama \& Andree (2010) explained the AISAS process that occurs started with a company that makes a product that can attract people's attention (attention). Then there will be consumer interest in the products they make (interest). Interested consumers will find out more about the product (search). Consumers who feel convinced by the information they find will buy the product (action). Then consumers who buy these products will provide information and experiences using these products to others (share).

The development of online marketing has penetrated the organic agriculture market in Indonesia. Marketers who develop organic food products for social media include Namaste Organic, Organic Kitchen, Tanihub, Winged Bean, Sayurbox, and many others. However, the reality cites statistical data and organic trends in 2016 published by the Research Institute of Organic Agriculture (Willer, et al. 2018) that Indonesia has not competed in the top ten markets and consumed organic food. The United States is in the first place as the country with the largest organic food market growth rate of $€ 38,938$. In contrast, Switzerland leads the country with the highest consumption level of organic food products ( $€ 274)$.
The demand for organic food increases all over the world (Juhl et al. 2017). If Indonesia can meet their needs and increase the export of organic products, it will certainly increase agricultural businesses' competitiveness (agribusiness) in Indonesia. Thus, it can increase foreign exchange and farm household income (Mayrowani, 2012). Indonesia still has the opportunity to develop organic agriculture with its potential.

The research of organic consumption by The Indonesian Consumers Foundation (YLKI, 2012) shows the low consumption of organic food in Indonesia. The low consumption of organic food is caused by the lack of information and public understanding (Noorjannah, 2012). Organic food literacy is important to inform and convince consumers that organic products bring many benefits for long-term life.

Based on Truman et al. (2019), the basic of literacy is defined as the ability to identify, understand, interpret, make, and form communication, both print and written, related to a particular context. Food literacy is often linked to a person's ability, understanding, and belief to make decisions that impact personal health and sustainable food systems (Cullen et al. 2015). Organic products include products with natural food ingredients that are free of various types of mixtures of hazardous chemicals such as fertilizers, antibiotics, and organisms produced by genetic engineering (Liu, et al. 2014). Considering the emergence of various diseases, there needs to be an effective strategy to help consumers obtain healthy organic food.

Factors that prevent consumers from buying organic product are access, affordability, knowledge, and belief regarding the benefits of organic products. Organic literacy is expected to increase consumer knowledge and understanding of organic products and create consumer purchase interest. So that consumers who use organic products believe and experience the benefits of these organic products and decide to switch from conventional products to organic products.

From some businessmen of organic food product, researchers choose to conduct data collection to the followers of Instagram, Facebook, and Twitter that belong to@sayurbox,@tanihub, and@dapurorganik, with respondents who live in Jabodetabek. 
Based on the case, this research aims to analyze the effect of social media on organic food literacy, analyze the effect of organic food literacy toward consumer purchase intention, and analyze the AISAS model's components that most effectively influence interest in purchasing organic food products online.

\section{METHODS}

Data used in this research were primary and secondary data. Primary data used in this study were obtained based on an online questionnaire distributed to social media followers of @sayurbox, @tanihub, and @ dapurorganik. Secondary data used in this research were obtained from (We Are Social, AOI, FiBL), books, journals, and the internet. There were 150 respondents involved in this research. Determination of the number of respondents was based on recommendations that the required number of samples had to be at least 5-10 times the number of indicators. The indicators in this research were 27 indicators.

The technique of collecting sample was purposive sampling quota. The criteria used in determining the sample were: (1) respondents were social media followers of Instagram, Facebook, and Twitter belonging to Sayurbox, Tanihub, and Organic Kitchen;
(2) followers who had never bought organic products;

(3) domiciled in Greater Jakarta (4) aged 18-45 years.

Data analysis techniques used quantitative analysis. Indicator measurements were made using a Likert scale with a value of 1 to 5 . The provisions of the Likert scale are: 1) Strongly Disagree, 2) Disagree, 3) Fairly Agree, 4) Agree, and 5) Strongly Agree.

Data processing of the research used descriptive analysis and SEM PLS analysis. Descriptive analysis was used to analyze the description of the characteristics of followers of @sayurbox, @ tanihub, and @dapurorganik social media accounts. According to (Ghozali, 2014), SEM is a multivariate statistical analysis technique to test the existence of a direct or indirect effect that is complex, both direct and indirect to produce a comprehensive picture of the model. SEM with PLS approach has high flexibility for researchers to link theory with data.

The SEM-PLS analysis in this research was used to analyze the direct effect of social media on organic food literacy and purchase intention based on AISAS modeling. The hypotheses in Table 1 are formulated in Figure 1 that shows the conceptual research framework.

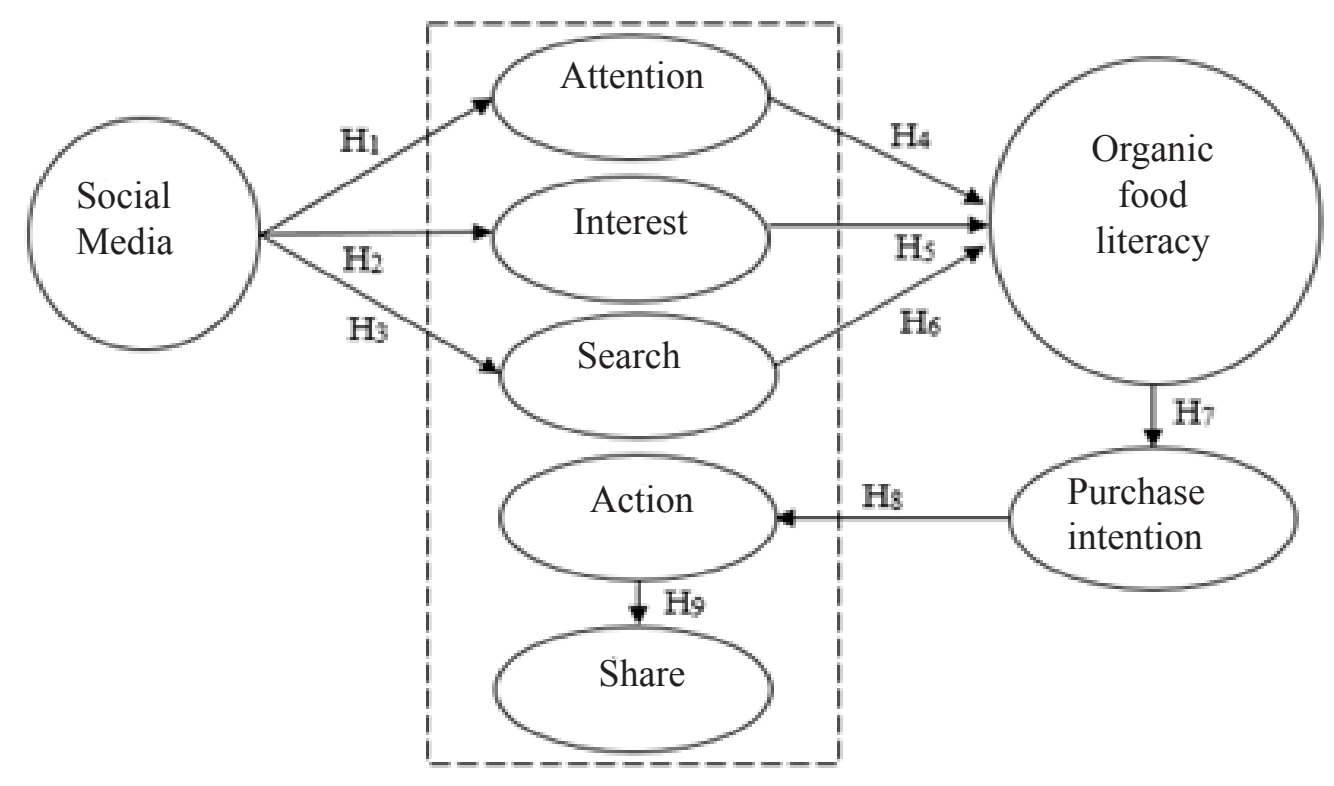

Figure 1. Framework of research 
Table 1. Research hypothesis

\begin{tabular}{clc}
\hline Hypothesis & Description & Path \\
\hline H1 & Social Media (MS) affects significantly toward attention (AT) & MS $\rightarrow$ AT \\
H2 & Social Media (MS) affects significantly toward interest (IN) & MS $\rightarrow$ IN \\
H3 & Social Media (MS) affects significantly toward search (SE) & MS $\rightarrow$ SE \\
H4 & Attention (AT) affects significantly organic food literacy (LPO) & AT $\rightarrow$ LPO \\
H5 & Interest (IN) affects significantly organic food literacy (LPO) & $\mathrm{IN} \rightarrow$ LPO \\
H6 & Search (SE) affects significantly organic food literacy (LPO) & SE $\rightarrow$ LPO \\
H7 & Organic food literacy (LPO) affects significantly toward purchase intention (MB) & LPO $\rightarrow$ MB \\
H8 & Purchase intention (MB) affects significantly toward action (AC) & MB $\rightarrow$ AC \\
H9 & Action (AC) affects significantly toward share (SH) & AC $\rightarrow$ SH \\
\hline
\end{tabular}

\section{RESULTS}

The results of the research were concluded by majority of answers in the questionnaire. Most respondents were women ( $89 \%$ of respondents). Most respondents were 23 to 28 years old ( $47 \%$ of respondents). Respondents lived in Jabodetabek, with the largest number came from Jakarta (60\% of respondents). Most respondents worked as private employees ( $48 \%$ of respondents). The most used type of social media was Instagram ( $92 \%$ of respondents).

\section{Analysis of Structural Equation Model - Partial Least Square (SEM-PLS)}

The analysis consisted of two parts that were outer model evaluation and inner model evaluation. This section, it will explain the evaluation of each model.

\section{Evaluation of Measurement Model (Outer Model)}

The first evaluation is Convergent Validity that requires value of outer loading $>0.5$ and AVE $>0.5$. If outer loading $>0.5$ but AVE value $<0.5$, it is necessary to drop the indicator with the value closest to 0.5 (Abdillah \& Hartono, 2016). The result of structural models can be seen in Figure 2 and Figure 3.

From the evaluation of the outer model in Table 2, seven indicators do not meet the requirements, such as LPO1, LPO2, LPO4, MB1, MB4, IN3, and SE2. Thus, they need to be eliminated or declared invalid in constructing constructs (latent variables). After removing the seven indicators, each variable's loading factor value met the specified rules of thumb.

Discriminant validity was measured by comparing the roots of AVE of a construct must be higher than the correlation between these latent variables or by looking at the value of cross-loading. A construct was considered reliable if it had a Cronbach's alpha value of 0.6 and a composite reliability value $\geq$ of 0.7 . All variables and indicators of structural model variables after dropping had construct reliability tests.

\section{Evaluation of Structural Model (Inner Model)}

Inner model or structural model test is conducted to predict causal relation between variable of hypothesis test. This test can be seen through the results of the coefficient of determination, predictive relevance, goodness of fit, as well as the path coefficient and parameter coefficient.

This research proposed nine hypotheses. The hypothesis test used bootstrapping analysis techniques. T-statistic could be used to identify the effect of the significance level between independent variables on the dependent variable. If the T-statistic value $>1.96$ (T-table of 5\% significance), the effect was significant and vice versa. Furthermore, based on the p-value, if the p-value $<\alpha$ (0.05), then H0 is rejected and vice versa (Ghozali, 2014). The results of Path Coefficients' followers of organic food social media using bootstrapping techniques are presented in Table 3. 


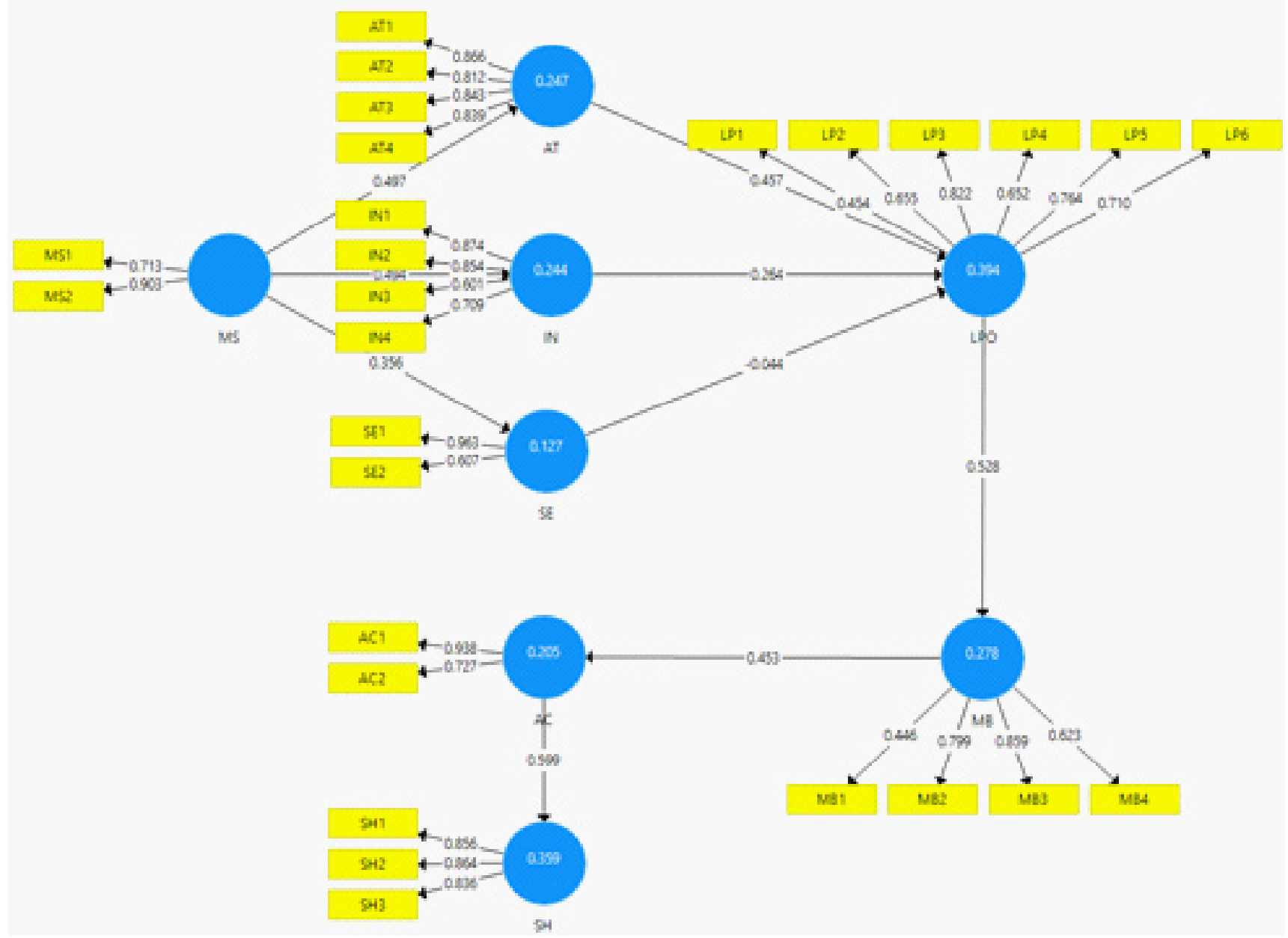

Figure 2. Outer model path diagram before dropping

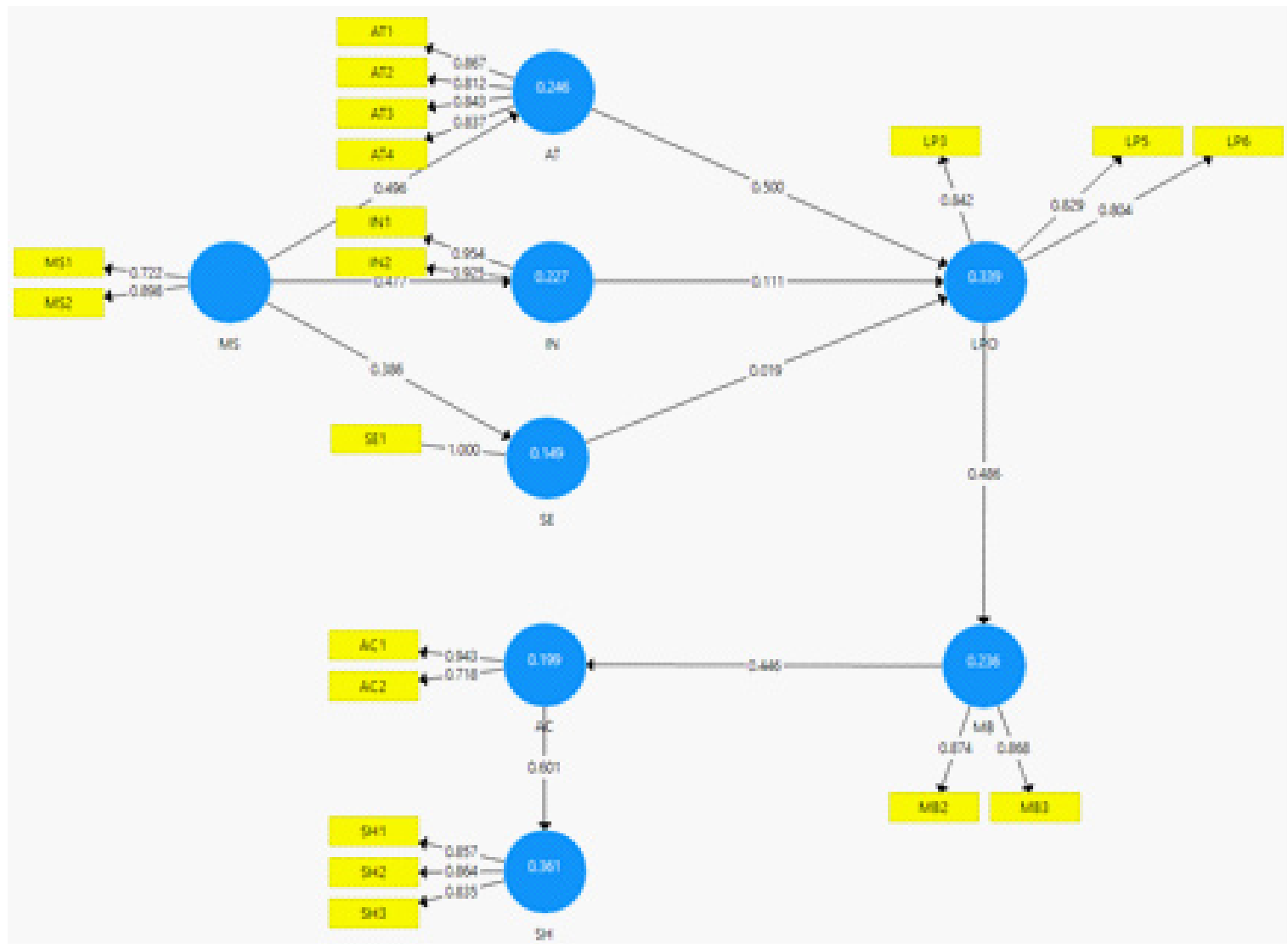

Figure 3. Outer model path diagram after dropping 
Table 2. Reliability and validity constructs

\begin{tabular}{lccc}
\hline Latent variable & Cronbach's alpha & Composite reliability & Average variance extracted (AVE) \\
\hline Social media & 0.611 & 0.796 & 0.663 \\
Organic food literacy & 0.768 & 0.865 & 0.681 \\
Purchase intention & 0.682 & 0.863 & 0.759 \\
Attention & 0.861 & 0.906 & 0.706 \\
Interest & 0.869 & 0.938 & 0.883 \\
Search & 1.000 & 1.000 & 1.000 \\
Action & 0.616 & 0.822 & 0.702 \\
Share & 0.813 & 0.888 & 0.726 \\
\hline
\end{tabular}

Table 3. Results of path coefficient test using bootstrapping technique

\begin{tabular}{lccc}
\hline & T Statistics & P Values & Hypothesis \\
\hline Social media $\rightarrow$ Attention & 8.840 & 0.000 & H1 is accepted \\
Social media $\rightarrow$ Interest & 7.173 & 0.000 & H2 is accepted \\
Social media $\rightarrow$ Search & 5.392 & 0.000 & H3 is accepted \\
Attention $\rightarrow$ Organic food literacy & 6.336 & 0.000 & H4 is accepted \\
Interest $\rightarrow$ Organic food literacy & 1.123 & 0.262 & H5 is rejected \\
Search $\rightarrow$ Organic food literacy & 0.216 & 0.829 & H6 is rejected \\
Organic food literacy $\rightarrow$ Purchase intention & 7.588 & 0.000 & H7 is accepted \\
Purchase intention $\rightarrow$ Action & 6.198 & 0.000 & H8 is accepted \\
Action $\rightarrow$ Share & 10.532 & 0.000 & H9 is accepted \\
\hline
\end{tabular}

\section{Hypothesis Test}

As shown in Table 3, the results of accepted hypotheses have a probability value of less than 0.05 , and the T-statistics value is greater than 1.96. From 9 hypotheses, 7 hypotheses are accepted and have significant effects, such as $\mathrm{H} 1, \mathrm{H} 2, \mathrm{H} 3, \mathrm{H} 4, \mathrm{H} 7, \mathrm{H} 8$, and $\mathrm{H} 9$; whereas $\mathrm{H} 5$ and $\mathrm{H} 6$ are rejected and have no significant effect.

\section{The Effect of Social Media toward Attention}

The statistic test results toward the first hypothesis showed that the path coefficient's value was $8.840 \geq$ 1.96 , and the significance of ( $p$-value $0.000<0.05$ ). Based on these results, it can be concluded that the first hypothesis is accepted. This is in accordance with Rihn and Khachatryan, et al. (2019), Oktimawati et al. (2018) and Kawano et al. (2011), who show that through messages that are able to invite attention, social media users will be interested in seeing more marketed products. The message that attracts attention is an initial step for online businesses to be known, recognized, and remembered by consumers.
The Effect of Social Media toward Interest

The second hypothesis results showed that the path coefficient's value was $7.173 \geq 1.96$, and the significance was (p-value $0.000<0.05$ ). Based on these results, it can be concluded that the second hypothesis is accepted. This is in accordance with Kim et al. (2017) and Gulseven (2018) that shows that social media followers like the messages and information conveyed, which will increase an individual interest in how social media is offered to promote the products offered.

\section{The Effect of Social Media toward Search}

The third hypothesis's statistic test results showed that the path coefficient's value was $5.392 \geq 1.96$ and the significance was ( $\mathrm{p}$-value $0.000<0.05$ ). Based on these results, it can be concluded that the third hypothesis is accepted. This indicates that social media affects an individual to search for further information before trusting information received, through various reference sources or asking friends and family (Morris et al. 2012) 
The statistic test results in the forth hypothesis showed that the value of the path coefficient was $6.336 \geq 1.96$ and significance was (p-value $0.000<0.05$ ). Based on these results, it can be concluded that the fourth hypothesis is accepted. This is in accordance with Hendriyani et al. (2013) that the higher attention they have certainly increased the understanding of organic products, including the attention placed by followers on understanding the benefits for health, the production process, and understanding of support for the sustainability of life in the future.

\section{The Effect of Interest toward Organic Food Literacy}

The fifth hypothesis's statistic test results showed that the path coefficient's value was $1.123 \geq 1.96$ and significance was ( $p$-value $0.262<0.05$ ). Based on these results, it can be concluded that the fifth hypothesis is rejected. It was caused by some followers of @sayurbox, @ tanihub, and @dapurorganik who were interested in joining the social media account just because they saw celebrity endorsements. Thus, this was not in line with research Malan et al. (2020) when an individual saw content posted by a social media account seller selling organic products and then feels interested. Absolutely, an individual would follow it. This interest will affect the process of finding more detailed information about organic products. Thus, the level of literacy will increase.

\section{The Effect of Search toward Organic Food Literacy}

The statistic test results in the sixth hypothesis showed that the path coefficient's value was $0.216 \geq 1.96$ and the significance was (p-value $0.829<0.05$ ). Based on these results, it could be concluded that the sixth hypothesis is rejected. Insignificance in the research results was because the reality that the community was still experiencing difficulties in finding sources of information that facilitate and discuss the process of organic food production, health benefits, impact on future survival, and so on that are attractively packaged through media content social. Thus, the results obtained are not in line with Ditzler and Greenhawt (2016) research results that the activity of searching for information after paying attention to the content of organic agriculture makes them interested in learning more information obtained, thus increasing their understanding of organic products.
The Effect of Organic Food Literacy toward Purchase Intention

Results of statistic test in seventh hypothesis showed that the value of the path coefficient was $7.588 \geq$ 1.96 and significance (p-value $0.000<0.05$ ). Based on these results, it can be concluded that the seventh hypothesis is accepted. This is in accordance with Slater (2013) when followers have high food literacy in the form of reliable food and nutritional information based on evidence that involves access, understanding and evaluation of information, and making decisions about what they consume. It will have a positive and significant effect on purchase intention. It means that the large and small understanding or belief in the community of organic food products is what will affect an individual's purchase intention.

The Effect of Purchase Intention toward Action

The statistic test results in the eighth hypothesis showed that the path coefficient's value was $6.198 \geq 1.96$ and significance was (p-value $0.000<0.05$ ). Based on these results, it can be concluded that the eighth hypothesis is accepted. It means that the effect of consumer interest considerations affects the decision-making process. This is in accordance with Abdurrahim et al. (2019) that followers will decide to buy products that are promoted when they already have a strong reason for decision making or action.

\section{The Effect of Action toward Search}

The results of the ninth hypothesis showed that the value of the path coefficient was $10.532 \geq 1.96$ and significance was ( $p$-value $0.000<0.05$ ). Based on these results, it can be concluded that the ninth hypothesis is accepted. Followers or consumers who have made a purchase or who have experience consuming organic food and feel it. They will be willing to provide positive testimonials through the comments column or by uploading it on a private social media account in the form of sharing photos or videos or often referred to as product reviews (Abdurrahim et al. 2019).

\section{Components of the AISAS Model That Most Affect Purchase Intention}

From five components of the AISAS model in Table 4, the component with the highest parameter coefficient is the variable share of 0.474 or $47.4 \%$. Thus, it can be 
concluded that the high level of share has the greatest influence on purchase intention. More and more people are willing to share on social media, becoming an effective new strategy for a marketer to gain trust and encourage the desire of potential customers to buy or be called purchase intention.

\section{Managerial Implication}

Based on the results of this study, organic literacy can still be improved. But there must be support from several parties such as businessman of organic products and the government. The results of this study indicate that social media has a positive and significant effect on the attention, interest, and search of consumers who follow social media accounts for selling organic products. This can be used by businessman to make better use of their social media accounts. Some steps that can be taken include creating social media content that contains information about organic agriculture such as the process of organic product production, organic product long-term benefit to sustainable health, availability, types, and how to distinguish organic products from packaging, labels or organic logos. This is expected to increase action and share in order to increase sales of organic products. The government can provide counseling to organic product businessman, both producers and distributors, to be able to effectively produce and sell organic products. Then by making public service advertisements on government-owned social media that are concerned with organic products, to invite people to be more interested in organic products.

\section{CONCLUSIONS AND RECOMMENDATIONS}

\section{Conclusions}

The results of this study indicate a significant and positive influence of social media on consumer attention, interest, and search factors. The availability of organic product in social media is deemed important to promote the health benefits of organic product and its difference to conventional product to increase consumer knowledge. Meanwhile, attention has a significant and positive effect on organic literacy. Social media has an important role in changing consumer knowledge and trust in organic products. Organic literacy has a significant and positive effect on buying interest. So it can be concluded that the high level of consumer understanding of organic products will lead to buying interest that leads to buying organic products (action). Action has a significant and positive effect on shares. Consumers who already have the experience of buying and using an organic product will want to share their experience with using organic products to their relatives or friends.

Share variable is the most influencing factor in consumer purchasing intention for organic product with the value of $47.4 \%$, followed by interest, attention, and search with a value of $14.5 \%, 10.2 \%, 6.0 \%$ respectively. This shows that the most influential factor for consumer awareness in purchasing organic products is testimonials from other people such as influencers, friends, and relatives. Thus, the more people who share positive experiences in using organic products, the more people will be more interested in buying organic products.

\section{Recommendations}

For further researcher, they are expected to explore more detail about social media marketing or digital marketing 4.0. Also, increasing the number of respondents so that research results will be closer to actual conditions such as Java and Outside Java. Organic food businesses need to pay attention to digital marketing techniques in social media marketing and put an analysis team and an admin that ensures that all organic agriculture information channels are always up to date.

Table 4. Results of path coefficient test using bootstrapping technique

\begin{tabular}{lcccc}
\hline & Original sample $(\mathrm{O})$ & T Statistics & P Values & Hypothesis \\
\hline Attention $\rightarrow$ Purchase intention & 0.102 & 1.131 & 0.259 & 3th place \\
Interest $\rightarrow$ Purchase intention & 0.145 & 1.440 & 0.150 & 2th place \\
Search $\rightarrow$ Purchase intention & 0.060 & 0.644 & 0.520 & 4rd place \\
Share $\rightarrow$ Purchase intention & 0.474 & 5.017 & 0.000 & 1st place \\
\hline
\end{tabular}




\section{REFERENCES}

Abdillah W, J Hartono. 2016. Partial Least Square (PLS): Alternatif Structural Equation Modeling (SEM) dalam penelitian bisnis. Yogyakarta: ANDI.

Abdurrahim MS, Najib M, DjoharS.2019. Development of AISAS model to see the effect of tourism destination. Journal of Applied Management 17(1):133-143. https://doi.org/10.21776/ ub.jam.2019.017.01.15.

Cullen $\mathrm{T}$ et al. 2015. Food literacy: definition and framework for action. Canadian Journal of Dietetic Practice and Research 76(3):140-145. https://doi.org/10.3148/cjdpr-2015-010.

Ditzler N, Greenhawt M. 2016. Influence of health literacy and trust in online information on food allergy quality of life and self-efficacy. Allergy, Asthma \& Immunology 117(3):258-263. https:// doi.org/10.1016/j.anai.2016.07.011.

Gulseven O. 2018. Estimating factors for the demand of organic milk in Turkey. Academy of Nutrition and Dietetics 120(9):2005-2016. https://doi. org/10.1108/BFJ-12-2017-0712.

Hendriyani, et al. 2013. Online Consumer Behaviour: Confirming the AISAS Model On Twitter Users. International Conference on Social and Political Science. hlm 25-26.

Juhl HJ, Fenger MH, Thøgersen J. 2017. Will the consistent organic food consumer step forward? An empirical analysis. Consumer Research 44(3):519-535.https://doi.org/10.1093/jcr/ ucx052.

Kaplan A, Haenlein M. 2010. Users of the world, unite! The challenges and opportunities of social media. Business Horizons (1):59-68. https://doi. org/10.1016/j.bushor.2009.09.003.

Kim SE et al. 2017. Effects of tourism information quality in social media on destination image formation: The case of Sina Weibo. Information \& Management 54(6):687-702. https://doi. org/10.1016/j.im.2017.02.009.

Kotler P, KL Keller. 2012. Marketing Management. 14 ed. United States of America: Pearson.

Liu R, Pieniak Z, Verbeke W. 2014. Food-related hazards in China: Consumers' perceptions of risk and trust in information sources. Food Control 46:291-298. https://doi.org/10.1016/j. foodcont.2014.05.033.
Malan H et al. 2020. Challenges, opportunities, and motivators for developing and applying food literacy in a University Setting: A Qualitative Study. Academy of Nutrition and Dietetics 120(1):33-34.

Morris MR, et al. 2012. Tweeting is Believing?: Understanding Microblog Credibility Perceptions. CSCW '12 Computer Supported Cooperative Work. USA. hlm 441-450.

Noorjannah S. 2012. Koordinasi pengembangan sayuran organik: pengembangan pangan organik di Indonesia dan institusi pendukung. http:// ditsayur.hortikultura.deptan.go.id/index.php. [18 Nov 2019]

Oktimawati NY, Primyastanto M, Abidin Z. 2018. Analysis of Social Media Relations to the Decision of Visiting in the Ria Beach Recreation Park of Kenjeran, Surabaya by AISAS Method (Attention, Interest, Search, Action, Share). Economic and Social of Fisheries and Marine 05(02):129-143. https://doi.org/10.21776/ ub.ecsofim.2018.005.02.02.

RihnA, Wei X, Khachatryan H. 2019. Text vs. logo: Does eco-label format influence consumers' visual attention and willingness-to-pay for fruit plants? An experimental auction approach. Behavioral and Experimental Economics 82:101452. https:// doi.org/10.1016/j.socec.2019.101452.

Slater J. 2013. Is cooking dead? The state of Home Economics Food and Nutrition education in a Canadian province. International Journal of Consumer Sudies 36837(6):617-624. https://doi. org/10.1111/ijcs.12042.

Sugiyama K, T Andree. 2010. The Dentsu Way: Secrets of Cross Switch Marketing from the World's Most Innovative Advertising Agency. United States: McGraw Hill Professional.

Truman E, Elliott C. 2019. Barriers to Food Literacy: A Conceptual Model to Explore Factors Inhibiting Proficiency. Nutrition Education and Behavior 51(1): 107-111.https://doi.org/10.1016/j. jneb.2018.08.008.

Willer H et al. 2018. The World of Organic Agriculture Statistics and Emerging Trend. Organic Agriculture FiBL. Switzerland: IFOAM. https://www.organic-world.net/index/newsorganicworld/article/1739.html. [23 Okt2019]

[YLKI] Yayasan Lembaga Konsumen Indonesia. 2012. Survey Konsumen Produk Pangan Organik. http://ylki.or.id/2011/08/survey-konsumenproduk-pangan-organik/. [22 Oct 2019]. 